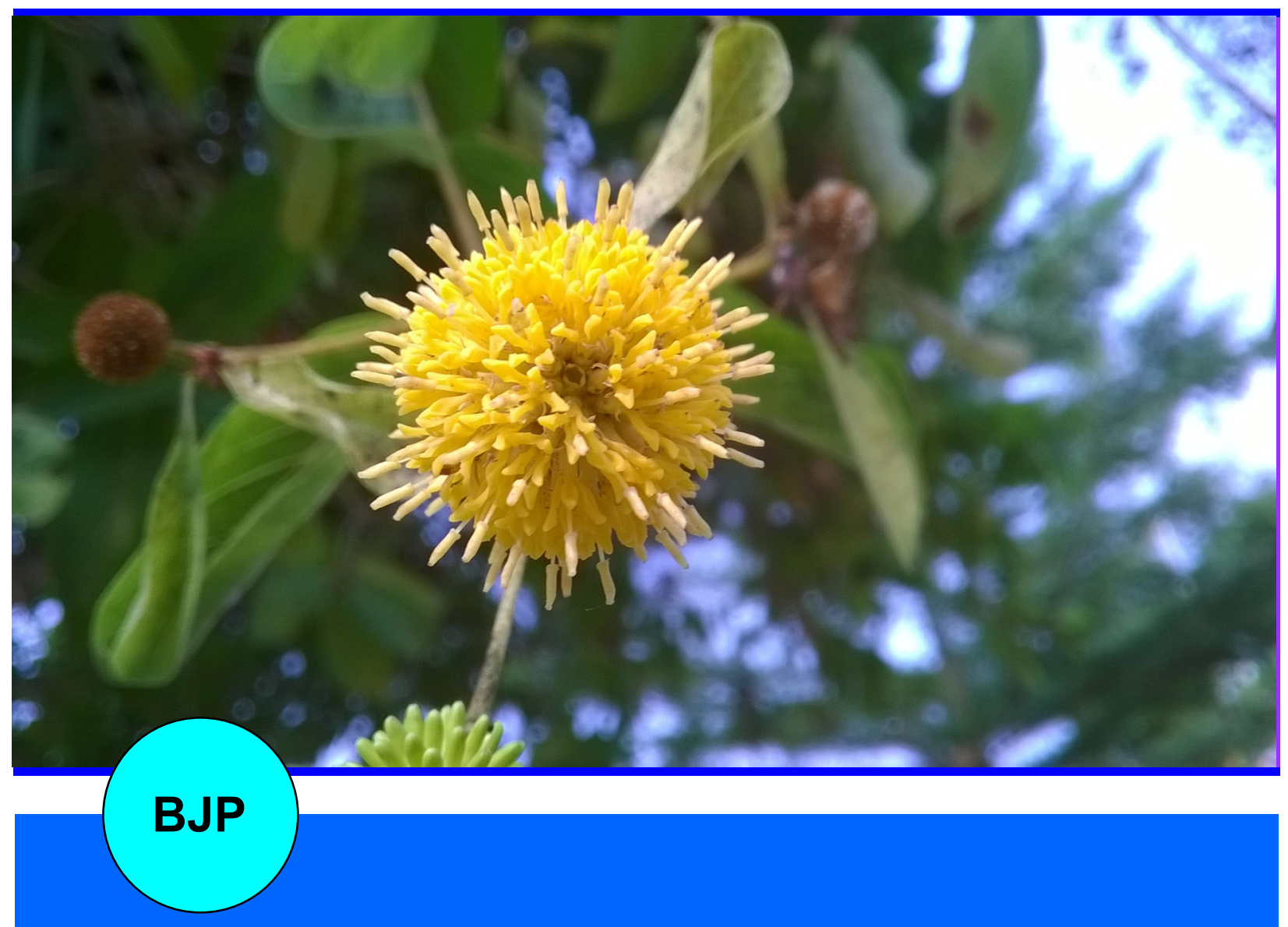

Bangladesh Journal of Pharmacology

Research Article

Antidiarrheal activity of ethanolic bark extract of Mitragyna diversifolia 
Abstracted/indexed in Academic Search Complete, Asia Journals Online, Bangladesh Journals Online, Biological Abstracts, BIOSIS Previews, CAB Abstracts, Current Abstracts, Directory of Open Access Journals, EMBASE/Excerpta Medica, Global Health, Google Scholar, HINARI (WHO), International

Pharmaceutical Abstracts, Open J-gate, Science Citation Index Expanded, SCOPUS and Social Sciences Citation Index;

ISSN: $1991-0088$

\title{
Antidiarrheal activity of ethanolic bark extract of Mitragyna diversifolia
}

\author{
Jebunnessa', Shaikh Bokhtear Uddin', M. Mahabub-Uz-Zaman², Rasheda Akter² \\ and Nazim Uddin Ahmed ${ }^{2}$
}

${ }^{1}$ Department of Botany, University of Chittagong, Chittagong 4331, Bangladesh; ${ }^{2}$ BCSIR Laboratories, Chittagong, Chittagong 4220, Bangladesh.

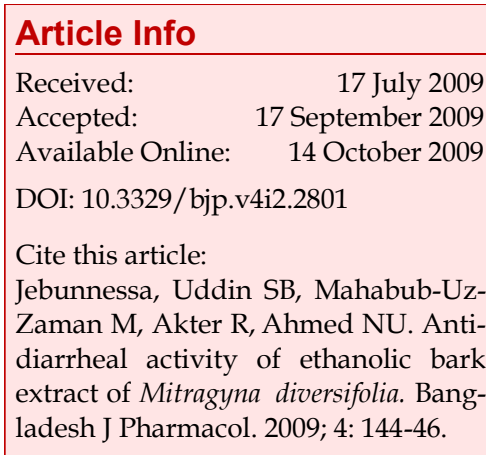

\section{Abstract}

The ethanolic bark extract of Mitragyna diversifolia showed significant $(p<0.05)$ antidiarrheal activity on gastrointestinal motility with barium sulfate milk model and castor oil-induced diarrheal model in rats. These results revealed that the bark extract possess pharmacological activity against diarrhea and may possibly explain the use of the plant in traditional medicine.

\section{Introduction}

Diarrheal diseases are one of the leading causes of morbidity and mortality in developing countries and are responsible for the death of millions of people each year (Carlos and Saniel, 1990). Despite immense technological advancement in modern medicine, many people in the developing countries still rely on the healing practices and medicinal plants for their daily health care needs (Ojewole, 2004). Therefore, the World Health Organization encouraged studies for the treatment and prevention of diarrheal diseases depending on traditional medical practices (Atta and Mouneir, 2004).

M. diversifolia [Local name- Kalikodom, Tribal nameThingkop (Bawm), Family- Rubiaceae)] is a small deciduous tree and frequently cultivated in the hilly area of Bangladesh. The bark of the plant is used traditionally by Bawm community of Bandarban district as remedy for diarrhea but has not been investigated for its antidiarrheal activity. The purpose of the present study was to find out the antidiarrheal activity of ethanolic bark extract of $M$. diversifolia in experimentally-induced acute diarrhea in rats.

\section{Materials and Methods}

\section{Animals and diet}

Male/female Albino rats obtained from the animal house of BCSIR laboratories, Chittagong, weighing between 150-200 g were used for the present study. The animals were acclimatized to room temperature $\left(28 \pm 5^{\circ}\right.$ C) with a relative humidity of $55 \pm 5 \%$ in a standard wire meshed plastic cages for 4 to 5 days prior to commencement of the experiment. During the entire period of study the animals were supplied with standard pellet diet and water ad libitum. In this study, all the animal experimentation was carried out according to the guidelines of Institutional Animal Ethics Committee (IAEC).

\section{Collection of plant materials}

Plant materials have been collected from various localities of Bandarban area. The plants have been selected according to their using information, frequently used and mode of use for diseases. The botanical identity of each plant has been prepared and information collected in the course of interviews taken from local people and traditional medicine practitioners of 
Bawm community by field observation, plant observation were recorded.

\section{Preparation of plant extract}

The fresh bark of $M$. diversifolia was washed finely, chopped in to small pieces, air dried under shade and ground in to powder form and stored in an airtight container. $450 \mathrm{~g}$ bark powder was macerated in $3 \mathrm{~L}$ pure ethanol (90\%) for 6 days at room temperature with occasional shaking. Every three days later, ethanol extract was filtered off through a cotton plug and finally with a Whatman No. 1 filter paper. The extract was concentrated under reduced pressure below $50^{\circ} \mathrm{C}$ through rotary vacuum evaporator. The concentrated extracts were collected in a Petri dish and air dried at room temperature. The whole process was repeated three times and finally deep brownish colored (bark) 25 g concentrated extracts was obtained which was kept in refrigerator at $4^{\circ} \mathrm{C}$.

\section{Gastrointestinal motility test with barium sulfate milk}

This experiment was carried out by the method described by Chatterjee (1993). Over night fasted fifteen Wistar Albino rats were randomly divided in to three equal groups $(n=5)$. Control group received only distilled water $2 \mathrm{~mL} /$ rat orally. Positive control group received commercially available anti diarrheal drug loperamide $1 \mathrm{mg} / \mathrm{kg}$ orally. Treated group received $M$. diversifolia bark extract $250 \mathrm{mg} / \mathrm{kg}$ orally. Thirty min later $2 \mathrm{~mL}$ of $10 \%$ barium sulfate solution were administered in all groups of rats. After $30 \mathrm{~min}$ rats were sacrificed. And the distance traveled by $\mathrm{BaSo}_{4}$ milk was measured and expressed as a percentage of the total length of small intestine (from pylorus to the ileo-cecal junction).

\section{Castor oil-induced diarrhea (Shoba and Thomas, 2001)}

Fifteen Wistar Albino rats were randomly divided in to three equal group $(n=5)$ control group, positive control group and treated group where control group received only distilled water $2 \mathrm{~mL} /$ rat, positive control group received loperamide $1 \mathrm{mg} / \mathrm{kg}$ as standard and treated group received $M$. diversifolia bark extract at the dose 2 $\mathrm{g} / \mathrm{kg}$ body weight. Rats were housed in separate cages having paper placed below for collection of fecal matters. Diarrhea was induced in rats by oral administration of castor oil $(1.0 \mathrm{~mL} / \mathrm{rat})$. Extract and drugs were given orally 1 hour before the administration of standard dose of $1.0 \mathrm{~mL}$ of castor oil. The number of both hard and soft pellet was counted at every hour over 6 hours period for each rat. Diarrhea was defined as the presence of stool with fluid material that stained the paper placed beneath the cages. Percent inhibition (PI) was calculated as follows:
$\mathrm{PI}=$

$\underline{\text { Mean defecation (Control group - Treated group) } \times 100}$ Mean defecation of controlgroup

\section{Data analysis}

All the values of antidiarrheal, tests were expressed as mean \pm SEM (Standard error of the mean). Statistical differences between the mean of the various groups were analyzed by using Students' t-test. Probability (p) value of 0.05 or 0.01 was considered as significant. All the graphical presentation and statistical calculations were prepared using "Microsoft Excel- 2000".

\section{Results}

M. diversifolia bark extract significantly $(\mathrm{p}<0.05)$ decreased the distance of gastrointestinal motility of rats from $55.7 \%$ (control group) to $43.6 \%$ (treated group) However, loperamide $(1 \mathrm{mg} / \mathrm{kg})$ exhibited much more marked reduction $36.8 \%$ with barium sulfate milk at 30 min study (Table I).

M. diversifolia bark extract significantly $(\mathrm{p}<0.01)$ inhibited the mean number of defecation when compared to control group and treated group (88.6\%) inhibition of the severity of diarrhea induced by castor oil was observed. The number of stools at $1^{\text {st }}, 2^{\text {nd }}, 3^{\text {rd }} 4^{\text {th }}$,

\begin{tabular}{|c|c|c|c|c|}
\hline \multicolumn{5}{|c|}{ Table I } \\
\hline \multicolumn{5}{|c|}{$\begin{array}{c}\text { Effect of } M \text {. diversifolia bark on gastrointestinal } \\
\text { motility with barium sulfate milk on rats }\end{array}$} \\
\hline \multirow[t]{2}{*}{ Treatment } & \multicolumn{4}{|c|}{ Gastro-intestinal motility } \\
\hline & $\begin{array}{l}\text { Length } \\
\text { of GIT } \\
(\mathrm{cm})\end{array}$ & $\begin{array}{c}\text { Length } \\
\text { passed } \\
\text { by } \mathrm{BaSO}_{4}\end{array}$ & $\begin{array}{c}\% \\
\text { Mo- } \\
\text { tility }\end{array}$ & $\begin{array}{c}\text { Mean } \pm \\
\text { SEM }\end{array}$ \\
\hline \multirow{5}{*}{$\begin{array}{l}\text { Distilled wa- } \\
\text { ter }(2 \mathrm{~mL} / \mathrm{rat} \text {; } \\
\mathrm{n}=5)\end{array}$} & 81 & 42 & 51.9 & \multirow{5}{*}{$55.7 \pm 1.3$} \\
\hline & 93 & 54 & 58.1 & \\
\hline & 115 & 51 & 53.0 & \\
\hline & 108 & 62 & 57.4 & \\
\hline & 112 & 65 & 58.0 & \\
\hline \multirow{5}{*}{$\begin{array}{l}\text { Loperamide } \\
(1 \mathrm{mg} / \mathrm{kg} ; \mathrm{n}= \\
5)\end{array}$} & 108 & 39 & 36.1 & \multirow{5}{*}{$36.8 \pm 0.9 b$} \\
\hline & 116 & 43 & 37.1 & \\
\hline & 80 & 29 & 36.3 & \\
\hline & 87 & 30 & 34.5 & \\
\hline & 95 & 38 & 40.0 & \\
\hline \multirow{5}{*}{$\begin{array}{l}\text { M. diversifolia } \\
\text { ethanolic bark } \\
\text { extract }(250 \\
\mathrm{mg} / \mathrm{kg} ; \mathrm{n}=5)\end{array}$} & 95 & 44 & 46.3 & \multirow{5}{*}{$43.6 \pm 3.4^{a}$} \\
\hline & 100 & 30 & 30.0 & \\
\hline & 108 & 51 & 47.2 & \\
\hline & 105 & 48 & 45.7 & \\
\hline & 103 & 50 & 48.5 & \\
\hline $\begin{array}{l}{ }^{a} \mathrm{p}<0.05 \text { and }{ }^{\mathrm{b}} \mathrm{p}< \\
\text { test) }\end{array}$ & signifi & compared & contrc & (Student's t- \\
\hline
\end{tabular}




\begin{tabular}{|c|c|c|c|c|}
\hline \multicolumn{5}{|c|}{ Table II } \\
\hline \multicolumn{5}{|c|}{ Effect of ethanol extract of $M$. diversifolia bark on castor oil induced diarrhea } \\
\hline Treatment & $\begin{array}{l}\text { Number of rats } \\
\text { with diarrhea }\end{array}$ & $\%$ Protection & $\begin{array}{c}\text { Mean defecation } \\
\text { within } 6 \text { hours study }\end{array}$ & $\begin{array}{l}\text { \%Inhibition } \\
\text { of defecation }\end{array}$ \\
\hline Distilled water (2 mL/rat) & $5 / 5$ & 0 & $7.0 \pm 0.3$ & - \\
\hline Loperamide $(1 \mathrm{mg} / \mathrm{kg})$ & $2 / 5$ & 60 & $0.4 \pm 0.2^{\mathrm{a}}$ & 94.2 \\
\hline $\begin{array}{l}\text { Bark extract of M. diversifolia } \\
(2 \mathrm{~g} / \mathrm{kg})\end{array}$ & $3 / 5$ & 40 & $0.8 \pm 0.4^{\mathrm{a}}$ & 88.6 \\
\hline Mean defecation values are expres & an \pm SEM. ${ }^{a} p<0$ & om & st-test) & \\
\hline
\end{tabular}

$5^{\text {th }}$ and $6^{\text {th }}$ hours for ethanol extract treated group was significantly $(p<0.01)$ decreased as compared to control group. The percent inhibition of defecation of $M$. diversifolia bark extract $(88.6 \%)$ was found almost comparable to the effect of standard anti diarrheal drug loperamide (94.2\%) (Table II).

\section{Discussion}

The aim of the present study was to assess the antidiarrheal effect of ethanolic bark extract of Mitragyna diversifolia in rats. The bark extract showed a significant $(p<0.05)$ activity against castor oil-induced diarrhea. The result is almost comparable to the effect of widely used antidiarrheal drug loperamide when tested at $1 \mathrm{mg} / \mathrm{kg}$. Castor oil is made up of $90 \%$ ricinoleate (Mekeon et al., 1999) which is metabolized to ricinoleic acid. Ricinoleic acid causes the irritation and inflammation in the intestinal mucosa, leading to release of prostaglandins, which stimulate the net secretion of water and electrolytes into the small intestine (Gaginella and Philips, 1975; Luderer et al., 1980). We speculate that that the antidiarrheal effects of ethanolic bark extracts may be due to the inhibition of prostaglandin biosynthesis. $M$. diversifolia bark extract also significantly $(\mathrm{p}<0.05)$ decreased the distance of gastrointestinal motility of rats.

The result of this study reveals that the bark extract of $M$. diversifolia contains pharmacologically active substances with antidiarrheal properties. These properties could be a potential source of modern pharmaceutical products. Further investigation is necessary for isolation, identification and characterization of different active compounds from the extract and for elucidating their mode of action, responsible for these properties on different biological systems.

\section{References}

Atta AH, Mouneir SM. Antidiarrheal activity of some Egyptian medicinal plant extracts. J Ethnopharmacol. 2004; 92: 303-09.

Carlos CC, Saniel MC. Etiology and epidemiology of diarrhea. Phillips J Microbio Infect Dis. 1990; 19: 51-53.

Chatterjee TK. Handbook on laboratory mice and rats. 1st ed. Kolkata, Department of Pharmaceutical Technology, Jadavpur University, 1993, p 157.

Gaginella TS, Phillips SF. Ricinoleic acid: Current view of ancient oil. Dig Dis Sci. 1975; 23: 1171-77.

Luderer JR, Dermers IM, Hayes AT. Advances in prostaglandin and thromboxane research. New York, Raven Press, 1980, pp 1633-38.

Mekeon TA, Lin A, Stafford AE. Biosynthesis of ricinoleate in castor oil. Adv Exp Med Biol. 1999, pp 46437-47.

Ojewole JAO. Evaluation of antidiarrheal, anti-inflammatory and antidiabetic properties of Sclerocarya birrea (A. Rich.) Hochst. stem bark aqueous extract in mice and rats. Phytotherapy Res. 2004; 18: 601-08.

Shoba FG, Thomas M. Study of antidiarrheal activity of four medicinal plants in castor oil-induced diarrhea. J Ethnopharmacol. 2001; 76: 73-76. 